\title{
Health education improve behavior and self-efficacy on personal hygiene among children with intellectual disability
}

\author{
Titiek Hidayati ${ }^{1}$, Akrom $^{2}$, Indri Nurasa ${ }^{3}$, Erviana $^{4}$ \\ ${ }^{1}$ Department of Epidemiology, Family Medicine and Public Health, Medicine and Health Science Faculty, \\ Universitas Muhammadiyah Yogyakarta, Indonesia \\ ${ }^{2}$ Department of Pharmacology, Pharmacy Faculty, Universitas Ahmad Dahlan, Indonesia \\ ${ }^{3,4}$ Magister Management of Nursing, Universitas Muhammadiyah Yogyakarta, Indonesia
}

\begin{tabular}{|c|c|}
\hline Article Info & ABSTRACT \\
\hline Article history: & Personal hygiene is one of the basic human needs and must be kept clean, \\
\hline Received Sep 14, 2019 & $\begin{array}{l}\text { including scalp and hair, eyes, nose, ears, nails of hands and feet, skin and } \\
\text { overall body care. Health education on personal hygiene is still concern not }\end{array}$ \\
\hline Revised Oct 20, 2019 & only for healthy children but also for children with disabilities. One of the ways \\
\hline Accepted Nov 27, 2019 & $\begin{array}{l}\text { is with audiovisual methods. This study aimed to analyze the effect of health } \\
\text { education on personal hygiene with audiovisual methods. The study design }\end{array}$ \\
\hline Keywords: & $\begin{array}{l}\text { used was pre-experiment without a control group. The number of samples was } \\
30 \text { using total sampling technique. Knowledge of personal hygiene before }\end{array}$ \\
\hline Attitude & $\begin{array}{l}\text { health education (pre-test) was mostly insufficient category, after being given } \\
\text { health education (post-test) mainly was in proper group. The pre-test attitude }\end{array}$ \\
\hline Behavior & was in low category, and the post-test was still the same. Pre-test and post-test \\
\hline Intellectual disability & of behavior were mostly being practiced. Pre-test and post-test of self-efficacy \\
\hline Knowledge & were in low category. There was an influence of health education on personal \\
\hline Personal hygiene & $\begin{array}{l}\text { hygiene with audiovisual methods on the level of knowledge in intellectually } \\
\text { disabled children }(p<0.05) \text {, but there was no effect on attitudes, behaviors, } \\
\text { and self-efficacy in intellectually disabled children. }\end{array}$ \\
\hline
\end{tabular}

Copyright $@ 2019$ Institute of Advanced Engineering and Science. All rights reserved.

\section{Corresponding Author:}

Akrom,

Department of Pharmacology, Pharmacy Faculty, Universitas Ahmad Dahlan,

Kapas 9 Road, Semaki, Umbulharjo, Yogyakarta 55166, Indonesia.

Email: akrom@pharm.uad.ac.id

\section{INTRODUCTION}

The number of Indonesians with disabilities is estimated at $2.45 \%$, and around $39.97 \%$ of them have more than one disability or disability [1-2]. The Central Statistics Agency published Susenas data, stating that 9.9 million Indonesian children are children with special needs in the category of persons with disabilities. Data on people with social welfare problems in 2016 describes that persons with disabilities based on regions/districts/cities in Yogyakarta Special Province (Kulon Progo, Bantul, Gunung Kidul, Sleman, and Yogyakarta) were 26177 people, specifically for the city of Yogyakarta numbering 1725 people. The intellectual category and type of mental retardation disability numbered 7181 people [3]. Children with disabilities or children with intellectual disabilities have delays and limitations in all developments so that the child has difficulty doing self-care [4], some self-skills such as eating, using the toilet, wearing and removing clothes, personal hygiene, and decorating [5]. Basic personal hygiene that must be considered includes scalp and hair care, eyes, nose, ears, hands and feet, skin and overall body care [6 ].

Personal hygiene in nursing is one of the basic human needs. Personal hygiene is a practice carried out by someone in maintaining or caring for self-hygiene, such as maintaining the cleanliness of hair, eyes, ears, nose, mouth, nails, genital, and clean appearance. Personal hygiene that is carried out on children is part of the maintenance effort in him, which includes sanitation and health to get physical fitness and prevent the emergence of disease [7]. Personal hygiene should be a concern not only for healthy children (who are not 
disabled) but also for children with disabilities. Children with disabilities have the right to get attention and protection from family, community, and government following Law Number 23 of 2002 about child protection and Law Number 36 of 2009 about health. Personal hygiene care aims to improve one's health status and as a form of disease prevention [3, 7-8].

Cleanliness itself has been regulated in the Qur'an and Al-Hadith, personal hygiene such as bathing, cleaning clothes, even before worshiping, which is cleaning yourself by washing. This is found in The QS. Al Baqarah (2): 222, which means: "Verily, Allah likes those who repent and likes those who purify themselves." God's Word in QS. Al Muddasir: 4-5 which means: "And clean your clothes. And sin, leave it". Al Hadist: "From Abu Malik Al-Ashariari said Rasulullah SAW said:"Sanctity is a condition of faith." (HR. Muslim). "Islam is a religion that is clean/holy, so you should maintain cleanliness. Surely you will not enter heaven, except for those who are holy "(HR. Baihaqi). Unclean and dirty if left attached to the body, it will cause disease or interference. Bathing or performing ablution so that the body becomes clean is something that has been taught in Islam [9]. The Prophet Muhammad was a messenger who was very concerned about health and cleanliness. Rasulullah SAW always reminded about the importance of maintaining health, cleanliness, and its effect on the purity of one's soul. Rasulullah SAW said: "Clean up what you are capable of because Allah established Islam above the joints of cleanliness. Do not enter heaven unless a clean person". Maintaining the cleanliness of the body and its possessions such as clothing, household appliances, and other objects that need to be kept clean are some of the things that are part of a Muslim's obligations [10].

Limitations in the process of thinking are the limitations possessed by children with disabilities, especially in terms of personal hygiene requires attention from parents in receiving information about personal hygiene that is associated with the level of knowledge possessed by children. Health education for children with disabilities can be improved by teaching continuously one of them is by using audiovisual methods. The progress and development of science and technology require humans to pass on knowledge to other humans. The audiovisual method is one of the learning methods in the form of slides containing pictures and sounds. Audiovisual media has a high level of effectiveness, according to research, on average above $60 \%$ to $80 \%$ [11].

The audio-visual method was used for the learning process in autistic children. The characteristics of autistic children are challenging to communicate and tend to be challenging to concentrate on one thing that is not interesting, so the use of audio-visual media is expected to attract autistic children's attention and can follow the movements shown. Based on previous research, audiovisual learning methods both partially and interactively, significantly influence the learning outcomes of children with special needs with autism, which are controlled by audiovisual and gender learning methods. Children with special needs, especially autistic children are one of the disorders is in communicating so that they need the help of the media in understanding learning material. Knowledge, if done, verbally will be intricate. One of the means for learning in children is the media. Children can be interested in using the right media. Learning success occurs if there is an interest in the learning process with the notes that the instructor can adjust to the interests and conditions of the students' media selection [12].

Nola J. Pender is an expert in nursing theory, a theory which he found to be very precise with this research topic. Pender introduces nursing theory: Nursing Promotion Model or Health Promotion Model (HPM). The application in HPM focuses on assessment factors that are believed to be able to influence changes in health behavior. Behavior that promotes health is the endpoint or forms of action that lead to the achievement of positive health such as optimal well-being, personal fulfillment, and productive life. Families with children who have disabilities need health efforts, one of which is to pay attention to how far children can receive and understand and practice personal hygiene. The aim is to assess the behavior (level of knowledge, attitude) and children with disabilities related to personal hygiene [12]. Exceptional education, exercises, providing experience, and skills about daily life are some of the efforts in reducing dependency and limitations in self-care [4]. Knowledge and skills can be provided in the form of health education. Health education is the process of making people able to improve and improve health, especially children with disabilities [13].

The results of a preliminary study conducted at Bantul 1 Special School and based on the results of interviews/information obtained from parents of students is that their children still feel capable of carrying out some personal hygiene activities, but sometimes their abilities are not in line with the results obtained. For example, if the child enters the bathroom, he will spend a long time in the bathroom, about 1 hour, and when he has finished bathing sometimes there is still soap or no brushing so that it even smells bad. The parents of the students, in this case the mother said that if bathing or brushing their teeth is not clean, the child will be taken back to the bathroom and assisted by his mother to clean it optimally. Based on the background and experience above, the researcher is interested in examining the effect of health education on personal hygiene with audiovisual methods on the behavior and self-efficacy of personal hygiene in mentally disabled children.

Int. J. Public Health Sci. Vol. 8, No. 4, December 2019: 391 - 399 


\section{RESEARCH METHOD}

The design of this study is a quantitative approach using an experimental design: pre-experiment with the design of the pretest-posttest group design. Respondents will be given a pretest first; after that, they are given treatment and after the procedure will be given a posttest [14]. The intervention group in this study is health education using audiovisual methods about personal hygiene. The population in this study were children with intellectual disability. The sample in this study were 30 children with intellectual disabilities at school age. There were three special schools included in this study, all located in Special Region of Yogyakarta, Indonesia. The technique used in this research is taking is total sampling. The protocol has been reviewed and approved by the ethics committee of the Faculty of Medicine and Health Sciences, Muhammadiyah University of Yogyakarta, no ethical clearance letter: 033/EP-FKIK-UMY/II/2019.

The instrument in this study was tested for validity using the product-moment correlation technique using Alpha Cronbach $(\alpha)$ with a significance level of 95\%. Reliability test using the Cronbach Alpha method with degrees of freedom $(\mathrm{df})=(\mathrm{n}-2)$ and $\alpha=0.05$ then if $\mathrm{r}$ arithmetic $>\mathrm{r}$ table, questions/statements are declared reliable or $\mathrm{r}$ arithmetic $\leq \mathrm{r}$ tables, questions are declared unreliable.

The prerequisite test is conducted to find out whether parametric data can be met or not [15]. Hypothesis testing of this study to prove the effectiveness of health education on personal hygiene with audiovisual methods on the behavior and self-efficacy of personal hygiene in intellectually disabled children, was analyzed using Paired T-test test statistics if the data were normally distributed and if the data were not normally distributed the hypothesis test used test Wilcoxon signed ranks test previously conducted a normality test using Shapiro Wilk with a sample less than 50.

\section{RESULTS AND DISCUSSIONS}

\subsection{Characteristics of research subjects}

Data from a total of 30 children were taken from three special schools in the Special Region of Yogyakarta. The characteristics of research subjects are shown in Table 1. Based on Table 1, most respondents were male and in the age group of 7-12 years old. There was no female respondent in Tegar Harapan School. Based on intellectual disability type, all respondents in Tegar Harapan and Muhammadiyah School were in mild type, while all respondents in Bangun Putra school were in medium type.

Table 1. Respondents' characteristics by the school $(n=30)$

\begin{tabular}{|c|c|c|c|}
\hline Variables & $\begin{array}{c}\text { Bangun Putra School } \\
\mathrm{n}(\%)\end{array}$ & $\begin{array}{c}\text { Tegar Harapan School } \\
\mathrm{n}(\%)\end{array}$ & $\begin{array}{c}\text { Muhammadiyah Schoo } \\
\mathrm{n}(\%)\end{array}$ \\
\hline \multicolumn{4}{|l|}{ Gender } \\
\hline Female & $3(30)$ & $0(0)$ & $6(46.1)$ \\
\hline Male & $7(70)$ & $7(100)$ & $7(53.9)$ \\
\hline \multicolumn{4}{|l|}{ Age group } \\
\hline $7-12$ & $10(100)$ & $7(100)$ & $10(76.9)$ \\
\hline $13-15$ & $0(0)$ & $0(0)$ & $3(23.1)$ \\
\hline \multicolumn{4}{|l|}{ Intellectual disability type } \\
\hline Mild & $0(0)$ & $7(100)$ & $13(100)$ \\
\hline Medium & $10(100)$ & $0(0)$ & $0(0)$ \\
\hline \multicolumn{4}{|l|}{ Paternal education } \\
\hline Junior high school & $2(20)$ & $0(0)$ & $1(7.7)$ \\
\hline High school & $8(80)$ & $5(71,4)$ & $11(84.6)$ \\
\hline Bachelor's degree & $0(0)$ & $2(28,6)$ & $1(7.7)$ \\
\hline \multicolumn{4}{|l|}{ Paternal occupation } \\
\hline Housewives & $10(10)$ & $5(71,4)$ & $12(92.3)$ \\
\hline Private employees & $0(0)$ & $2(28,6)$ & $1(7.7)$ \\
\hline \multicolumn{4}{|l|}{ Paternal income } \\
\hline Less than minimum wage & $10(10)$ & $5(71,4)$ & $12(92.3)$ \\
\hline Minimum wage & $0(0)$ & $2(28,6)$ & $1(7.7)$ \\
\hline
\end{tabular}

The highest number of respondents based on paternal education were in the high school category, in all school. None of the respondents in Tegar Harapan School had parents with junior high school education, and none in Bangun Putra School had parents with bachelor's degrees. Most respondents had housewife mothers and parental income of less than regional minimum wage. 


\subsection{Pre-post-test on knowledge, attitude, behavior, and self-efficacy on personal hygiene}

The mean value of knowledge, attitude, practice, and self-efficacy before and after health education was shown in Table 2, while the changes in category for each variable before and after health education was shown in Table 3. The mean value for each variable increased significantly after the education, as shown in Table 2. The highest increase is on the behavior variable, with an increase of 1.83 .

Table 2. Scores of knowledge, attitudes, behaviors, and self-efficacy on personal hygiene before and after health education $(n=30)$

\begin{tabular}{|c|c|c|c|}
\hline Variables & Measurement & Minimum-Maximum & Mean \pm SD \\
\hline \multirow{2}{*}{ Knowledge } & Pretest & $2.00-8.00$ & $6.03 \pm 1.51$ \\
\hline & Posttest & $5.00-8.00$ & $7.06 \pm 0.82$ \\
\hline \multirow{2}{*}{ Attitude } & Pretest & $5.00-16.00$ & $11.56 \pm 2.86$ \\
\hline & Posttest & $8.00-16.00$ & $12.26 \pm 1.52$ \\
\hline \multirow{2}{*}{ Behavior } & Pretest & $8.00-14.00$ & $11.73 \pm 1.70$ \\
\hline & Posttest & $10.00-45.00$ & $13.56 \pm 6.86$ \\
\hline \multirow{2}{*}{ Self-efficacy } & Pretest & $0.00-3.00$ & $1.93 \pm 0.86$ \\
\hline & Posttest & $0.00-3.00$ & $2.10 \pm 0.88$ \\
\hline
\end{tabular}

Table 3. Knowledge, attitude, behavior, and self-efficacy on personal hygiene before and

\begin{tabular}{|c|c|c|c|}
\hline \multicolumn{2}{|c|}{ Variables } & $\begin{array}{c}\text { Pretest } \\
n(\%)\end{array}$ & $\begin{array}{c}\text { Posttest } \\
n(\%)\end{array}$ \\
\hline Knowledge & $\begin{array}{c}\text { Poor } \\
\text { Sufficient } \\
\text { Good }\end{array}$ & $\begin{array}{c}6(20) \\
13(43.3) \\
11(36.7)\end{array}$ & $\begin{array}{c}1(3.3) \\
6(20) \\
23(76.7)\end{array}$ \\
\hline Attitude & $\begin{array}{l}\text { Poor } \\
\text { Sufficient } \\
\text { Good }\end{array}$ & $\begin{array}{c}25(83.3) \\
1(3.3) \\
4(13.3)\end{array}$ & $\begin{array}{c}29(96.7) \\
0(0) \\
1(3.3)\end{array}$ \\
\hline Behavior & $\begin{array}{l}\text { Did not practiced } \\
\text { Practiced }\end{array}$ & $\begin{array}{c}8(26.7) \\
22(73.3)\end{array}$ & $\begin{array}{c}3(10) \\
27(90)\end{array}$ \\
\hline Self-efficacy & $\begin{array}{l}\text { Low } \\
\text { High }\end{array}$ & $\begin{array}{c}21(70) \\
9(30) \\
30(100)\end{array}$ & $\begin{array}{c}18(60) \\
12(40) \\
30(100)\end{array}$ \\
\hline
\end{tabular}

Table 3 shows that there was an increase in knowledge after being given health education, from sufficient category to the proper category. There was no difference in attitude before and after health education, but there was an increase in practiced category for behavior variable and in high category for self-efficacy variable. Meanwhile, knowledge of personal hygiene are presented in Table 4.

Table 4. Knowledge of personal hygiene before and after health education by school $(\mathrm{n}=30)$

\begin{tabular}{|c|c|c|c|}
\hline School & Knowledge & $\begin{array}{c}\text { Pretest } \\
n(\%)\end{array}$ & $\begin{array}{c}\text { Posttest } \\
n(\%)\end{array}$ \\
\hline \multirow[t]{3}{*}{ Bangun Putra } & Poor & $1(10)$ & $0(0)$ \\
\hline & Sufficient & $5(50)$ & $2(20)$ \\
\hline & Good & $4(40)$ & $8(80)$ \\
\hline \multirow[t]{3}{*}{ Tegar Harapan } & Poor & $1(14.3)$ & $1(14.3)$ \\
\hline & Sufficient & $3(42.9)$ & $1(14.3)$ \\
\hline & Good & $3(42.9)$ & $5(71.4)$ \\
\hline \multirow[t]{4}{*}{ Muhammadiyah } & Poor & $4(30.8)$ & $0(0)$ \\
\hline & Sufficient & $5(38.5)$ & $3(23.1)$ \\
\hline & Good & $4(30.8)$ & $10(76.9)$ \\
\hline & Total & $30(100)$ & $30(100)$ \\
\hline
\end{tabular}

Based on Table 4, Muhammadiyah School experienced most changes in the knowledge, as they had the highest increase in children with good knowledge after health education. One of the factors that influence knowledge is the age factor of which the majority of respondents were in the 7-12 years age range of 27 respondents with each special school; Bangun Putra School has ten respondents, Tegar Harapan School has 
seven respondents, and Muhammadiyah School 13 respondents. Children with intellectual disabilities at the age of 7-12 years are not yet mature to receive any information. Knowledge about personal hygiene in mentally disabled children is only obtained from experience and information from parents and teachers. However, health education about personal hygiene has never been done by other parties outside the school. Health education is the right approach to increase health knowledge because health education is more focused on prevention efforts[4, 14].

Health education in this study uses the audio-visual method by watching videos containing sound and movement in practicing personal hygiene activities. This is in line with previous research, which states that video media is used to facilitate respondents in receiving information submitted by researchers [9]. The results of previous studies, namely [1] the use of torso media can improve the ability of teachers to carry out learning in the first cycle an average of 2.8 and a percentage of $70 \%$. Increase in the second cycle an average of 3.8 and a percentage of 95\%. [2] The use of torso media in learning can improve student learning outcomes, namely cycle I, the total number of student scores by 200, and an average value of 66.67 increased in cycle II by 240 and an average value of 80 . Torso media can group into visual media. Visual media are media that only rely on the sense of sight. This visual media displays still images such as film strips, photo slides, pictures or paintings, and prints. There are also visual media that show moving images or symbols such as silent films and cartoon films $[16,17]$.

Personal menstrual hygiene behavior is less influenced by knowledge [9]. Education is the most critical domain for the formation of one's actions. Behavior can be changed by providing information. Someone who has more sources of information will have more knowledge as well [14]. Based on Table 4 that an increase in knowledge after being given health education. Then it became clear that when the mental retardation knowledge of 23 respondents occurred, it would automatically affect personal hygiene behavior with the help of individual hygiene control sheets that were filled every day for 2 weeks. Hence, attitude on personal hygiene are showed in Table 5.

Table 5. Attitude on personal hygiene before and after health education by the school $(n=30)$

\begin{tabular}{cccc}
\hline School & Attitude & $\begin{array}{c}\text { Pretest } \\
\mathrm{n}(\%)\end{array}$ & $\begin{array}{c}\text { Posttest } \\
\mathrm{n}(\%)\end{array}$ \\
\hline \multirow{3}{*}{ Bangun Putra } & Poor & $8(80)$ & $9(90)$ \\
& Sufficient & $1(10)$ & $0(0)$ \\
& Good & $1(10)$ & $1(10)$ \\
Tegar Harapan & Poor & $5(71,4)$ & \\
& Sufficient & $0(0)$ & $7(100)$ \\
& Good & $2(28.6)$ & $0(0)$ \\
Muhammadiyah & Poor & $12(92.3)$ & $0(0)$ \\
& Sufficient & $0(0)$ & $13(100)$ \\
Total & Good & $1(7.7)$ & $0(0)$ \\
& & $30(100)$ & $0(0)$ \\
\hline Source: Primary Data, 2019 & & &
\end{tabular}

Based on the results of the measurement of attitudes in Table 5, there were no positive changes in children with intellectual disability after health education. The results of the attitude category did not experience a difference in either the pre-test or post-test categories with fewer categories. Personal hygiene is influenced by various factors such as society, family and individual awareness and attitudes about cleanliness. Most health problems affecting school students can be prevented by promoting good hygiene practices through families and adopting good health education [18].

Table 6 shows that the school that experienced most changes was Tegar Harapan School, with all children practiced personal hygiene behavior after health education. Behavioral categories change but are not significant. The results of the action of respondents' pretest and posttest are in the practiced category. Children with intellectual disabilities need help from others in meeting their needs. Parental assistance is required to encourage adaptive behavior in mentally disabled children [19]. The link between health education with mental retardation behavior is that they will support each other if parents encourage and support mental retardation activities, especially in fulfilling personal hygiene activities.

Parenting that is owned by parents in terms of quality and intensity of the attention given by parents will affect the attitudes and behavior of children. Some factors that influence parenting includes educational background, occupation, and socioeconomic conditions[20]. Previous study conducted on school-age children who are not disabled shows that during the 6 months the intervention, there was a significant increase in the level of knowledge, attitudes, and practices in schools and continuing health education programs about personal hygiene with the involvement of parents/guardians of students will have a greater impact on 
a significant increase in the level of knowledge, attitudes and practices of students about personal hygiene [21]. The research can be a reference material for further research so that the expected results can be significant.

Table 6. Behavior on personal hygiene before and after health education by the school $(n=30)$

\begin{tabular}{cccc}
\hline School & Behavior & $\begin{array}{c}\text { Pretest } \\
n(\%)\end{array}$ & $\begin{array}{c}\text { Posttest } \\
n(\%)\end{array}$ \\
\hline \multirow{2}{*}{ Bangun Putra } & Did not practiced & $1(10)$ & $0(0)$ \\
& Practiced & $9(90)$ & $10(100)$ \\
Tegar Harapan & Did not practiced & $3(42.9)$ & $0(0)$ \\
& Practiced & $4(57.1)$ & $7(100)$ \\
Muhammadiyah & Did not practiced & $4(30.8)$ & $3(23.1)$ \\
& Practiced & $9(69.2)$ & $10(76.9)$ \\
& Total & $30(100)$ & $30(100)$ \\
\hline
\end{tabular}

Source: Primary Data, 2019

Other research explains that mentally disabled children have intelligence below the average who will experience barriers to their adaptive behavior, thus requiring the help of others in meeting their needs. The results of his research on "the effect of health education with demonstration methods on handwashing behavior in mentally retarded children" shows that the method of handwashing demonstration helps mentally retarded children to think so that children get involved, things that have been seen serve as examples to be practiced with guided practice and improve his behavior in daily life as expected [22].

The results of the personal hygiene control sheet carried out for two weeks showed that the majority of own hygiene activities experienced increased inactivity. Several children had well personal hygienes (30 respondents) $(100 \%)$. This is consistent with previous research that there is the effect of health education on menstrual care on menstrual personal hygiene behavior in adolescent girls with mental retardation in Bantul 1 Special School [9].

Table 7 reveals that school with most changes in self-efficacy was Bangun Putra School, with two children managed to increase their self-efficacy from low to the high category after health education. Children with autistic disabilities, who are already independent, are not accompanied by parents and are ordered by parents to be able to carry out stages of personal hygiene activities such as brushing their teeth, washing their hands, washing their hair, combing their hair, and toilet training. This shows that autistic children who are independent do not have doubts and can be more responsible for themselves [8]. When correlated with the results of self-efficacy in Table 3 , it can be concluded that the self-efficacy of mentally disabled children will be high if the child is able and confident to carry out personal hygiene activities independently.

Table 7. Self-efficacy on personal hygiene before and after health education by the school $(\mathrm{n}=30)$

\begin{tabular}{|c|c|c|c|}
\hline School & Self-efficacy & $\begin{array}{c}\text { Pretest } \\
F(\%)\end{array}$ & $\begin{array}{c}\text { Posttest } \\
F(\%)\end{array}$ \\
\hline \multirow[t]{2}{*}{ Bangun Putra } & Low & $8(80)$ & $6(60)$ \\
\hline & High & $2(20)$ & $4(40)$ \\
\hline \multirow{2}{*}{ Tegar Harapan } & Low & $4(57.1)$ & $4(57.1)$ \\
\hline & High & $3(42.9)$ & $3(42.9)$ \\
\hline \multirow[t]{3}{*}{ Muhammadiyah } & Low & $9(69.2)$ & $8(61.5)$ \\
\hline & High & $4(30.8)$ & $5(38.5)$ \\
\hline & & $30(100)$ & $30(100)$ \\
\hline
\end{tabular}

Source: Primary Data, 2019

Factors that require attention in increasing self-efficacy of students with special needs in inclusive schools are the availability of assessment space, the availability of teachers who assist students individually, the management of inclusive class systems, and the skills of classroom teachers in guiding and directing students with special needs to optimize its potential. This shows that self-efficacy in carrying out daily activities, especially personal hygiene requires the skills of people who provide health education so that the potential of the child is optimal and is applied at home [23].

\subsection{Hypothesis prerequisite test}

The normality test was done as hypothesis prerequisite test. The results of the normality test can be seen in Table 8 . Table 8 shows that not all variables have a significance value higher than $0.05(\mathrm{p}>0.05)$. It can be stated that the results of the pre-test and post-test distribution were not entirely distributed normally. Hypothesis test was then performed using the Wilcoxon signed ranks test. 
Table 8 . Normality test results on knowledge, attitude, behavior, and self-efficacy on personal hygiene $(\mathrm{n}=30)$

\begin{tabular}{cccc}
\hline Variable & Measurement & Statistic & $\mathrm{p}$ \\
\hline \multirow{2}{*}{ Knowledge } & Pretest & 0.826 & 0.000 \\
& Posttest & 0.842 & 0.000 \\
Attitude & Pretest & 0.956 & 0.250 \\
& Posttest & 0.854 & 0.001 \\
Behavior & Pretest & 0.931 & 0.052 \\
& Posttest & 0.403 & 0.000 \\
Self-efficacy & Pretest & 0.853 & 0.001 \\
& Posttest & 0.829 & 0.000 \\
\hline Source: Primary
\end{tabular}

\subsection{Effects of health education using audio-visual methods on personal hygiene-related knowledge, attitude, behavior, and self-efficacy}

Effects of health education using audio-visual methods in children with intellectual disability on their personal hygiene-related knowledge, attitude, behavior, and self-efficacy were shown in Table 9. Table 9 shows that the mean rank at the time of the pretest with the lowest value was in the self-efficacy variable, and the highest value was in the attitude variable. The mean rank value at the posttest with the lowest value is in the self-efficacy variable, and the highest value is in the behavior variable. The mean rank value at the pretest and posttest on the knowledge variable obtained a significant value of $0.006(\mathrm{p}<0.05)$, it can be stated there was an effect of health education about personal hygiene with audio-visual methods on knowledge in children with intellectual disability.

Table 9. Wilcoxon signed ranks test results on personal hygiene-related knowledge, attitude, behavior, and personal self-efficacy hygiene $(n=30)$

\begin{tabular}{ccccc}
\hline Variable & Measurement & Mean Rank & $\mathrm{p}$ & $\mathrm{z}$-score \\
\hline \multirow{2}{*}{ Knowledge } & Pretest & 9.17 & 0.006 & -2.758 \\
& Posttest & 13.61 & & \\
Attitude & Pretest & 12.35 & 0.183 & -1.331 \\
& Posttest & 14.22 & & \\
\multirow{2}{*}{ Behavior } & Pretest & 10.32 & 0.292 & -1.054 \\
& Posttest & 14.35 & & \\
Self-efficacy & Pretest & 7.00 & 0.225 & -1.213 \\
& Posttest & 7.78 & &
\end{tabular}

Source: Primary Data, 2019

The increase in knowledge that occurs in mentally disabled children after being given health education is due to daily exposure to their hygiene activities. A few hours after being given health education, mentally disabled children indirectly practice the results of the knowledge they have acquired at school. This is supported by previous research, which states that: increasing student knowledge after being given health education is due to measurements made at the end of menstruation. Students still remember the procedure for maintaining the cleanliness of the reproductive organs because they had just practiced cleaning the organs [16]. Previous research states that there is an effect of repeated baseball game techniques on increasing the gross motor skills of children with mild mental retardation Ungaran Special School. Significant improvement occurred in several aspects of gross motor skills such as walking, running, throwing, catching, and hitting, but the gross motor that did not affect was jumping, jumping, and kicking [24].

Coordination of eye and hand movements is the excellent motor ability that appears in the development and growth of children when they are active, especially in mildly retarded children. Children can easily carry out daily activities if their eye and hand coordination are excellent and vice versa if their eye and hand coordination abilities are limited, making it difficult for children to perform daily tasks. Fine and gross motor skills that are trained and carried out repeatedly will make it easier for children to do their daily activities. Based on this research, activities carried out frequently can also be applied mainly in conducting personal hygiene [24-25].

Individuals who experience intellectual disabilities or disabilities are vulnerable to health hazards either as a direct consequence of their inability or due to a lack of awareness regarding personal and environmental hygiene. Developmental children are not aware of personal hygiene at the school level. For better knowledge and practice, health education intervention programs are essential for growing children for their better health and future [10]. 
This research has also applied the nursing theory that has been put forward by Nola J. Pender, namely Health Promotion Model (HPM). HPM in this study is to provide health education using audiovisual methods for mentally disabled children. The success of the method used will be closely related to the behavior of respondents in the past, such as parenting, role models, patterns of daily habits. Other factors are personal factors: biological factors such as age, gender, and children with intellectual disabilities; psychological factors such as motivation and self-competence; and sociocultural factors such as race and economic status. These factors play close role in the success of the methods used in delivering health education. The higher self-efficacy will lower the inhibiting factor in shaping behavior and practicing behavior in health education [26].

Interpersonal influence, that is, family support in the form of the family helps fill in the control sheet while monitoring the implementation of routine personal hygiene activities and situational influences are two influences that can directly or indirectly influence the behavior of mentally disabled children to practice or not practice the health education that has been delivered. Knowledge acquired by an intellectually disabled child will affect behavior and attitudes, while self-efficacy or self-confidence in the abilities of the mentally disabled child will affect the child's behavior [27-28].

There were some limitations to this study. This study was only done for four days. It should be even longer, but due to the constraints between the time of research almost close to the schedule of student examinations. The other limitation was that the sample taken is the minimum sample, which is 30 respondents, due to restrictions in obtaining samples that match the inclusion criteria. Other than that, the study was conducted in one class that was combined with children with different disability categories, for example students with autism, so that made other students less focused.

\section{CONCLUSION}

This research concluded that the audio-visual method used for health education on personal hygiene could affect intimate hygiene-related knowledge on children with intellectual disability, but no significant effects found on attitude, behavior, and self-efficacy. Attitude and self-efficacy on personal hygiene were in low category, while the response was on the practiced type. It is recommended to conduct further research to identify the right strategy in giving professional health education on children with disabilities with more extended study periods. We recommended to schools to provide continuous health education for students and parents on keeping personal hygiene.

\section{ACKNOWLEDGMENT}

This work was supported by Ministry of Research Technology and Higher Education Republic of Indonesia [Number 7/E/KPT/2019].

\section{REFERENCES}

[1] Fox MH, Witten MH, Lullo C. Reducing Obesity Among People With Disabilities. J Disabil Policy Stud. 2014;25(3):175-85.

[2] Cameron L, Suarez DC. Disability in Indonesia: What can we learn from the data? 2017;(August):1-65. Available from: https://www.monash.edu/_data/assets/pdf_file/0003/1107138/Disability-in-Indonesia.pdf

[3] UNESCO, UIS. Education and Disability: Analysis of Data from 49 Countries. Inf Pap N 49 [Internet]. 2018;March 2018(March). Available from: http://uis.unesco.org/sites/default/files/documents/ip49-education-disability-2018en.pdf

[4] Ge T, Zhang Q, Lu J, Chen G, Sun M, Li X. Association between education and health outcomes among adults with disabilities: Evidence from Shanghai, China. PeerJ. 2019; 2019(2).

[5] Bergström H, Hagströmer M, Hagberg J, Elinder LS. A multi-component universal intervention to improve diet and physical activity among adults with intellectual disabilities in community residences: A cluster randomised controlled trial. Res Dev Disabil. 2013;34(11):3847-57.

[6] Kasim EVAR, Fransiska A, Lusli M, Siradj O, For C, Studies D, et al. The situation of people with disability in Indonesia : a desk review. 2010;(November).

[7] Courtney-Long EA, Stevens AC, Carroll DD, Griffin-Blake S, Omura JD, Carlson SA. Primary care providers' level of preparedness for recommending physical activity to adults with disabilities. Prev Chronic Dis. 2017;14(11):1-12.

[8] Dewi KW. The Role of Parenting Parents Against Personal Hygiene Independence in Autistic Children in SDN Experiment Surabaya. J Pendidik Khusus. 2017;9(2).

[9] Prasetyaningrum S. The Effect of Health Education on Menstrual Care on Menstrual Personal Hygiene Behavior in

Int. J. Public Health Sci. Vol. 8, No. 4, December 2019: 391 - 399 
Adolescent Girls with Mental Retardation in SLB Negeri 1 Bantul. STIKES 'Aisyiyah Yogyakarta; 2015.

[10] AbouZeidHassan O, Karmalawy EMAH, RazekMohammed AA. Knowledge and Practices of Personal Hygiene among Mentally Retarded Students at El-Fikrya Schools in Minia Governorate, Egypt. IOSR J Nurs Heal Sci. 2019;8(3):33-43.

[11] Windrum P, García-Goñi M, Coad H. The Impact of Patient-Centered versus Didactic Education Programs in Chronic Patients by Severity: The Case of Type 2 Diabetes Mellitus. Value Heal [Internet]. 2016;19(4):353-62. Available from: http://dx.doi.org/10.1016/j.jval.2016.01.014

[12] Hithersay R, Strydom A, Moulster G, Buszewicz M. Carer-led health interventions to monitor, promote and improve the health of adults with intellectual disabilities in the community: A systematic review. Res Dev Disabil. 2014;35(4):887-907.

[13] Zuurmond M, O'Banion D, Gladstone M, Carsamar S, Kerac M, Baltussen M, et al. Evaluating the impact of a community-based parent training programme for children with cerebral palsy in Ghana. PLoS One. 2018; 13(9):1-17.

[14] Notoatmodjo S. Health Research Methodology. Jakarta: PT Rineka Cipta; 2010.

[15] Doherty AJ, Jones SP, Chauhan U, Gibson JME. An integrative review of multicomponent weight management interventions for adults with intellectual disabilities. J Appl Res Intellect Disabil. 2018;31(April 2017):39-51.

[16] Rozi LHS. The Influence of Health Education with Audio Visual Media on Hygine Vulva Knowledge during Menstruation in Tuna Grhahita Students in SLB Muhammadiyah Gamping Yogyakarta. Universitas 'Aisyiyah Yogyakarta; 2019.

[17] Sakrani, Halidjah S, Margiati KY. Improved Learning Outcomes of Students with Physical Disabilities Using Torso Media. J Pendidik dan Pembelajaran Khatulistiwa. 2013;2(7).

[18] Hazazi A, Chandramohan S, Khan J, AL-Mohaithef M. Knowledge Attitude and Practices Regarding Personal Hygiene among the Male Primary School Children in Abha, Kingdom of SaudiArabia: A Cross-Sectional Study. Helix. 2018;8(2):3215-23.

[19] Ferrari M, Sussman MB, editors. Childhood Disability and Family Systems. Vol. 53, Journal of Chemical Information and Modeling. London: Haworth Press, Inc.; 2016.

[20] Holden GW. Parenting: A Dynamic Perspective. 2nd ed. California: SAGE; 2015.

[21] Mukherjee A, Sinha A, Taraphdar P, Haldar D. Effectiveness of an educational intervention on personal hygiene among school children in slum area of Kolkata, India. IOSR J Dent Med Sci. 2014;13(12):13-7.

[22] Roheti YE, Windyastuti E, Pangesti CB. The Effect of Health Education with Demonstration Methods on Handwashing Behavior in Children with Physical Disabilities in SLB Karanganyar Regency. STIKes Kusuma Husada Surakarta; 2018.

[23] Muhtarom T. Self Efficacy Students with Special Needs in Education in Inclusive Schools. J Pendidik Ke-SD-an. 2016;2(2).

[24] Indardi N. Repetition of Castles Game Techniques Against Improvement of Coarse Motor Ability in Children with Light Developmental Disabilities. J Phys Educ Heal Sport. 2015;2(1):44-9.

[25] Heller T, Scott HM, Janicki MP, Heller T, Esbensen A, Fazio S, et al. Caregiving, intellectual disability, and dementia: Report of the Summit Workgroup on Caregiving and Intellectual and Developmental Disabilities. Alzheimer's Dement Transl Res Clin Interv. 2018;4:272-82.

[26] Alligood MR, editor. Nursing Theorists and Their Work. 8th ed. Missouri: Mosby Elsevier; 2014.

[27] Spanos D, Melville CA, Hankey CR. Weight management interventions in adults with intellectual disabilities and obesity: A systematic review of the evidence. Nutr J [Internet]. 2013;12(1):1. Available from: Nutrition Journal

[28] Bernabe-Ortiz A, Diez-Canseco F, Vasquez A, Kuper H, Walsham M, Blanchet K. Inclusion of persons with disabilities in systems of social protection: a population-based survey and case-control study in Peru. BMJ Open. 2016;6(8):e011300. 